\title{
LUTZ JAEGER
}

Albrecht Kessler

The HartX Period May 1992, Seen Against the Background of Twenty Years of Energy Balance Climatology at the Hartheim Pine Plantation 


\title{
The HartX Period May 1992, Seen Against the Background of Twenty Years of Energy Balance Climatology at the Hartheim Pine Plantation
}

\author{
L. Jaeger and A. Kessler
}

With 8 Figures

Received July 14, 1994

Revised February 6, 1995

\begin{abstract}
Summary
The experimental site of the Department of Meteorology of Freiburg University at the Hartheim pine stand is first described. There, since 1973 long term measurements of net radiation and its components have been carried out. In addition we have been monitoring the different heat fluxes and components of the forest water budget.

From May 11th to May 24th 1992 a special international and interdisciplinary observation period was organized in Hartheim (HartX 92). This took place in the frame of the international regional climatic project REKLIP (Regionales Klima Projekt). We then describe the permanent equipment and the special HartX installations. After that we show the climate of the region, in May 1992 and the weather during the HartX period. It was extraordinarily warm and the precipitation was much less than normal. The cloud cover was very small.

We report the results of the radiation measurements (net radiation and its components). They are compared to the long standing measurements (1974-1988). Moreover the longstanding data of the components of the water budget (throughfall, canopy drip and stemflow, interception and transpiration) of the period 1978-1985 are dealt with. In addition we report the behaviour of the energy fluxes (soil-stand heat flux, turbulent sensible and latent heat fluxes) of the period 1974-1988. These estimations are compared to the conditions in May 1992 and the conditions during HartX 92.
\end{abstract}

\section{Introduction}

The project "Radiation, heat and water balance climatology of a pine stand near Hartheim" started in 1973. Our objective was to monitor the net radiation and its components, the turbulent heat fluxes as well as the storage terms in the stand and the soil and other meteorological data over long term periods. In addition we are evaluating all the components of the water budget of a forest ecosystem. In this context the typical features of the climatological variations of the above mentioned parameters are studied. Moreover we try to give a response to the question whether the heat and water balance components are related to modifications and changes in the silvicultural ecosystem, caused by stand growth, thinnings or influences of weather and climate.

At present we do not have many such data sets (Miller, 1981; Kessler, 1985a; Hantel, 1989; Baumgartner, 1990). But these data are necessary for investigating global climatic change and its impact on the ecology of the planet earth.

From May 11th to 24th 1992 a special operation period was carried out within the framework of the REKLIP experiment at the Freiburg University Department of Meteorology climatological pine stand site at Hartheim. This intensive measurement campaign was called Hartheimer Experiment (HartX). Scientific intentions were: investigation of the soil-plantatmosphere interaction at a long term well 
monitored site with particular interest to the energy and mass fluxes; comparisons of methods, redundant measurements and investigation of the relations to the arable land surrounding the forest.

The Regio Klima Projekt (REKLIP) has been ongoing since the year 1991 in the southern part of the rift valley of the Upper Rhine on the territories of Germany, France and Switzerland (Parlow, this issue).

The feature of HartX was that further international researchers took part besides the working groups of REKLIP. The results of the investigations of these different groups are jointly published in this special issue of TAC. The following experimentalists are engaged in Meteorology, Climatology, Hydrology, Biology, Forestry and Physical Geography:

\section{Participants of REKLIP}

1. Meteorologisches Institut der Universität Freiburg, Germany (MIF)

2. Institut für Physische Geographie der Universität Freiburg, Germany (IPG)
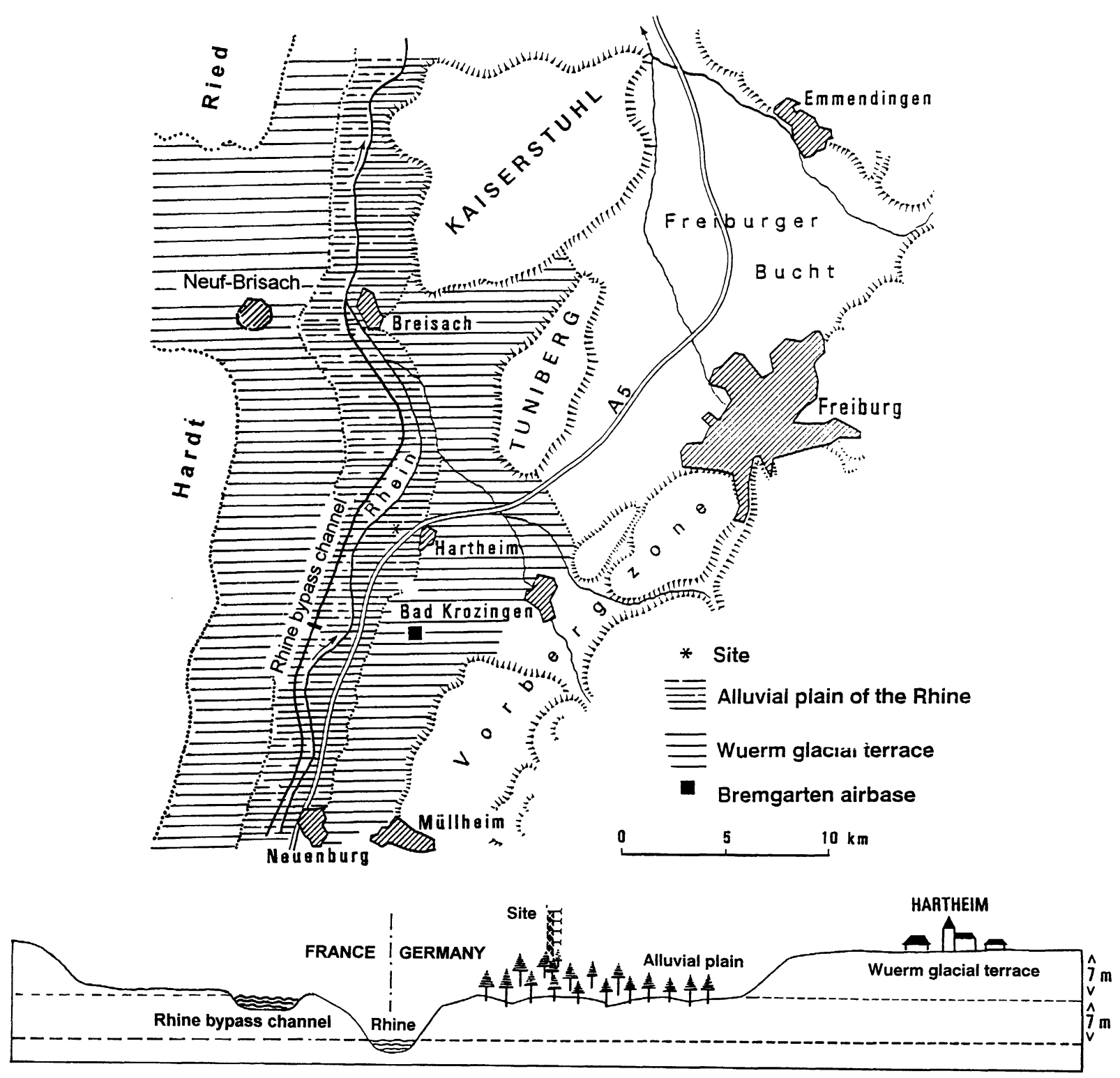

Fig. 1. Map of the experimental site and its surroundings and cross-section of the alluvial valley with the location of the Hartheim pine forest station of the Meteorological Institute of Freiburg University 
3. Paul Scherrer Institut, Villigen, Switzerland (PSI)

4. Geographisches Institut der Universität Basel, Switzerland (MCR)

5. Centre d'Etudes et de Recherches Eco-Géographiques, Université Louis Pasteur, Strassbourg, France (CEREG)

Non REKLIP members

6. Bayreuther Institut für terrestrische Ökosystemforschung, Bayreuth, Germany (BITÖK)

7. Institut für Meteorologie und Physik der Universität für Bodenkultur, Vienna, Austria (IMP)

8. School of Renewable Natural Resources, University of Arizona, Tucson, USA (RNR)

9. Eidgenössische Forschungsanstalt für Wald, Schnee und Landschaft, Birmensdorf, Switzerland (WSL)

10. Institut de la Recherche Agronomique, Laboratoire de Bioclimatologie et d'Ecophysiologie Forestière, Champenoux, Nancy, France (INRA)

In the following we use the abbreviations in parentheses.

\section{The Experimental Site}

The experimental site is located in the lower part of the Upper Rhine valley near the village of Hartheim, $20 \mathrm{~km}$ south-west of Freiburg (see Fig. 1 and Fig. 2). Detailed site descriptions have been given earlier (Jaeger, 1978; Schott, 1980; Merkel, 1987; Kessler et al., 1988). Geographical coordinates are $47^{\circ} 56^{\prime} \mathrm{N}, 7^{\circ} 37^{\prime} \mathrm{E}$ and the altitude is $201 \mathrm{~m}$ above sea level. The area is a highly uniform flood plain (Fig. 2). The approximate dimension of the forest is $10000 \mathrm{~m}(\mathrm{~N}-\mathrm{S})$ and $1500 \mathrm{~m}$ (W-E). Using a tower height to fetch relationship of 1:100, the site has sufficient fetch in the prevailing wind direction (SSW). The minimum fetch is $1: 30$. Due to river regulation and the sealed Rhine bypass channel the groundwater table has dropped to $7 \mathrm{~m}$ below the surface. Groundwater uptake by the trees is not possible.

The site is considered to be an ideal place to carry out radiation measurements. The view of the horizon is reduced by values of less than three degrees.

Some remarks should be made concerning the biometrical data of the Hartheim pine plantation. Different findings resulted from a) the different formulations of the question by the investigators, b) different methods of determination and c) inhomogeneities of the measurements in time.

The best investigated data set given by MIF are the mean stand heights (Fig. 4). It is the only homogeneous data set to characterize the development of the stand. Eight pilot trees are measured twice a year giving the mean stand height. During HartX we had a mean stand height of $11.5 \mathrm{~m}$ (range $10-14 \mathrm{~m}$ ).

In 1992 the trees (pinus sylvestris) were 33 years old. Cultivation work reduced the number of trees per hectare in the years 1970/1971, 1981/1982 and 1991/1992 (Fig. 4). During HartX the mean stand density was 5600 trees per hectare related the total Hartheim pine plantation area. The tree density of all living trees with a diameter at breast height of at least $5 \mathrm{~cm}$ was 3873 trees per hectare related to an area of $3000 \mathrm{~m}^{2}$ around the towers were we had five plots of evaluation (BITÖK and CEREG). BITÖK, CEREG and INRA evaluated further biometrical stand parameters in the near surroundings of the towers and presented the following values:

mean diameter at breast

height $(\mathrm{m}): 0.11$ (range $0.05-0.23$ )

cumulative circumference

at breast height (m/ha): 1320

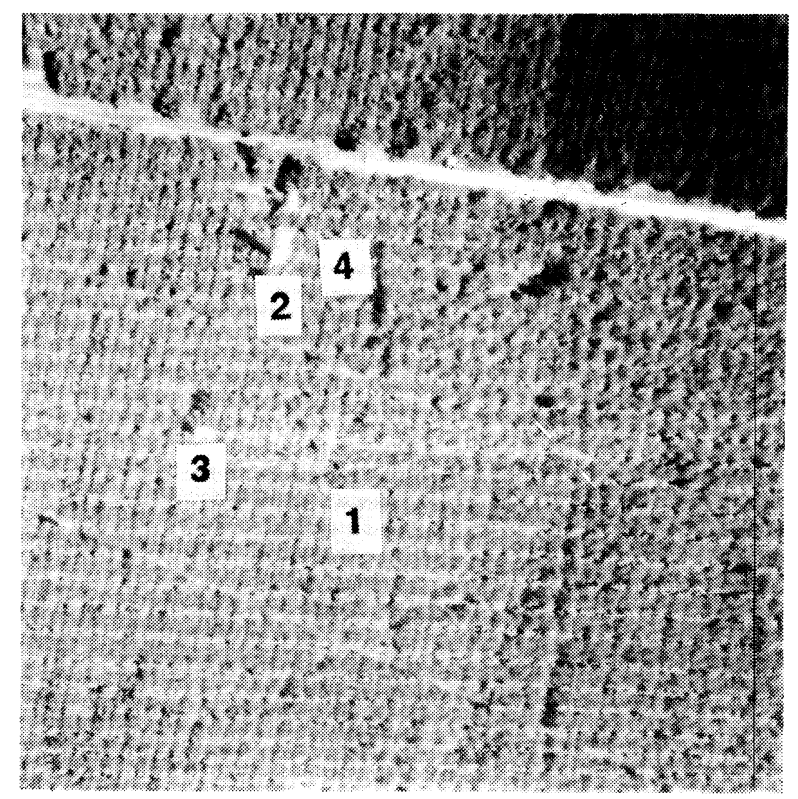

Fig. 2. Aerial photograph of the Hartheim site with its narrow surrounding. 1: recording cabin 2: big tower 3: small tower 4: pneumatic tower 
cumulative basal area

$\left(\mathrm{m}^{2} / \mathrm{ha}\right): \quad 38$

sapwood area $\left(\mathrm{m}^{2} / \mathrm{ha}\right): 26$ (Granier, INRA)

The discrepancy in measurements of the leaf area index (LAI) at Hartheim site principally results from the application of different methods. Heiderich (1989) found an increasing value of projected LAI of 3.71 to 3.78 from April 1988 to April 1989 by means of a biomass harvest. In May 1992 Joss and Graber (this issue) estimated projected LAI-values between 2.6 and 2.8 (optical evaluation by means of LiCor LAI-2000; only leaf area, i.e. without twigs and stems). Sturm (MIF) and Köstner (BITÖK) reported 2.8 (by means of a biomass harvest of 5 trees in 1993).

The LAI of the understory during HartX was estimated to amount to 1.5 (Wedler et al., this issue).

For the year 1979 Künstle et al. (1979) reported a biomass value (dry matter) of the pinus sylvestris stand of $4.36 \mathrm{~kg} / \mathrm{m}^{2}$. With a mean biomass specific weight of $470 \mathrm{~kg} / \mathrm{m}^{3}$ a biomass layer of $0.93 \mathrm{~cm}$ in thickness was estimated. In 1992 Köstner (BITÖK) reported 6.6, 7.3 and $8.6 \mathrm{~kg} / \mathrm{m}^{2}$, depending on the methods used (e.g.

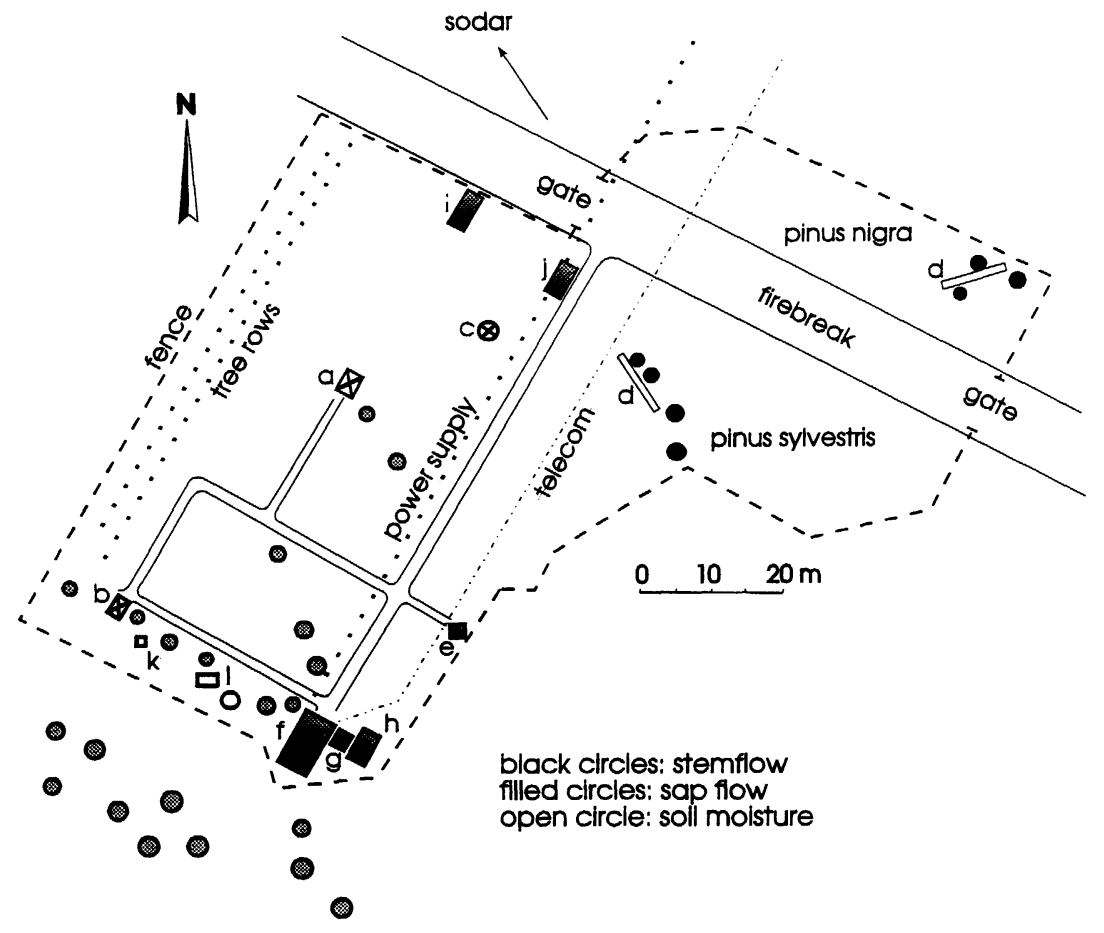

-

Fig. 3. Schematical true to scale representation of the experimental site Hartheim with the standard and the special HartX installations. $a$ : Big tower $(30 \mathrm{~m}$ height), firstly with the permanent installations to monitor the temperature and humidity profile above the canopy by means of psychrometers, the wind profile above the canopy and the wind direction, the components of the net radiation and the precipitation managed by MIF; secondly the MCR HartX installations, in detail, psychrometers, solarimeters and a net radiometer, anemometers and finally three eddy correlation devices. $b$ : Small tower (18 m height) with precipitation and radiation sensors of MIF; an interchanging Bowen ratio-energy balance recording system of IMP, two onepropeller eddy correlation systems (OPEC, RNR) and krypton humidity sensors of RNR. $c$ : Pneumatic $30 \mathrm{~m}$ tower of PSI with valves at different heights to measure concentrations of $\mathrm{O}_{3}, \mathrm{CO}_{2}, \mathrm{H}_{2} \mathrm{O}$ and $\mathrm{NO}_{\mathrm{x}}$ as well as meteorological parameters. $d$ : Throughfall and canopy drip measurements of MIF, associated with stemflow recording. $e$ : Stevensons screen. $f$ : Recording cabin (MIF and guests). $g$ : Battery power supply. $h$ : Hut for materials. $i$ and $j$ : Recording trailers (MCR and PSI). $k$ : Measurement of soil temperature (MIF). l: Heat flux plate (MIF). To the north of the firebreak pinus nigra trees were planted, pinus sylvestris is the coniferous species to the south of it. A SODAR was operated by MCR in a distance of approximately $500 \mathrm{~m}$ in the direction of the arrow 


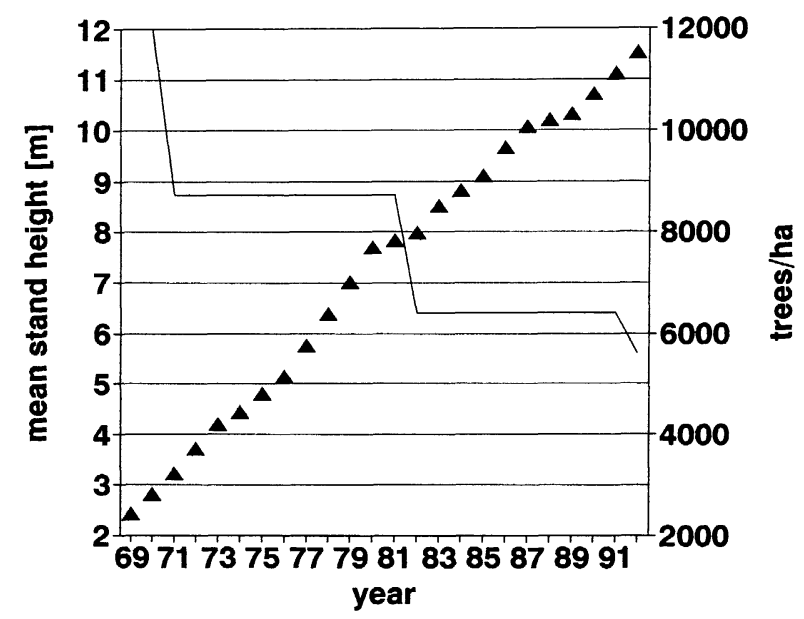

Fig. 4. Development of the Hartheim pine plantation from 1969 to 1991 , measured by MIF. Triangles give the mean stand height, the solid line shows when thinnings have been carried out

using Schobers yield tables); Sturm and Köstner reported 10.1 for the year 1993 according to a biomass harvest of 5 trees.

Figure 3 shows a schematic, true to scale representation of the experimental site of Hartheim with the installations during HartX.

\section{The Climate and the HartX Weather Situation}

The climate of the central part of the southern Rhine rift valley is characterized by relatively high temperatures and low precipitation (Table 1). The inferior precipitation amounts and enhanced temperatures compared to other regions in South-west Germany are a result of foehn effects from the Black Forest and Vosges mountains to the east and to the west and of the relatively low lying Rhine river plain. A majority of precipitation is observed in the summer season. The number of days with more than $0.1 \mathrm{~mm}$ precipitation is 170 .

Percolation and surface runoff is negligible below the pine stand. The mean annual amount of evapotranspiration $(E)$ therefore equals precipitation $(P)$, namely $E=P$.

Following Kessler et al. (1988), the evapotranspiration

$E=E_{I n}+E_{T r}$

is partitioned into an amount of $37 \%$ for interception $\left(E_{I n}\right)$ and a value of $63 \%$ for transpiration $\left(E_{T r}\right)$ (Table 2). $E_{T r}$ includes evapotranspiration of the understory vegetation and a small amount of evaporation from the soil. Until the middle of the 1980s no substantial understory development was observed because of the high shadow rates on the forest floor. So the assumption of very small amounts of understory evapotranspiration was valid during this period. After the last thinning the understory vegetation was considerably enhanced. According to Wedler et al. (this issue) the soil and understory evapotranspiration is $20 \%$ of the stand evapotranspiration during the HartX period. It is not possible to generalize the HartX results that easily. But they signify a hint that for future calculations the water

Table 1. Average Monthly and Yearly Means of Temperature $T\left({ }^{\circ} \mathrm{C}\right)$ and Precipitation $P(\mathrm{~mm})$ of Bremgarten Meteorological Observatory, $3.2 \mathrm{~km}$ South-east of Hartheim Pine Stand site of MIF (period 1951-1980)

\begin{tabular}{|c|c|c|c|c|c|c|c|c|c|c|c|c|c|}
\hline & $\mathbf{J}$ & $\mathrm{F}$ & $\mathbf{M}$ & A & $\mathbf{M}$ & $\mathbf{J}$ & $\mathbf{J}$ & A & $S$ & $\mathrm{O}$ & $\mathbf{N}$ & D & $Y$ \\
\hline $\mathrm{T}$ & 0.9 & 2.2 & 5.8 & 9.3 & 13.7 & 17.0 & 19.0 & 18.2 & 15.0 & 9.8 & 5.2 & 1.7 & 9.8 \\
\hline $\mathbf{P}$ & 42 & 37 & 41 & 48 & 72 & 83 & 69 & 86 & 55 & 42 & 50 & 42 & 667 \\
\hline
\end{tabular}

Table 2. Components of the Water Budget ( $\mathrm{mm}$ ) of the Hartheim Pine Stand, Mean Values 1978-1985

\begin{tabular}{lllll}
\hline & Precipitation & $\begin{array}{l}\text { Throughfall, } \\
\text { Canopy drip, } \\
\text { Stemflow TS }\end{array}$ & $\begin{array}{l}\text { Interception } \\
E_{\text {ln }}\end{array}$ & $\begin{array}{l}\text { Transpiration } \\
E_{T r}\end{array}$ \\
\hline Year & 647 & 411 & 236 & 406 \\
Nov-Apr & 248 & 140 & 108 & 116 \\
May-Oct & 404 & 275 & 129 & 299 \\
\hline
\end{tabular}


vapour flux at the forest floor is no longer negligible.

As a result of the uniform moistening of the canopy during the course of the year-every second day we observe precipitation occurrence the interception in the summer and in the winter season is nearly equal. Interannual changes are also very small. The ratio of summer transpiration to winter transpiration is 2.6. Oscillations from year to year of the transpiration amount are in the same magnitude as the precipitation variations.

From May 12th till the end of the experiment the HartX area was influenced by an anticy- clone. On May 17th the local airmass was replaced by somewhat dryer and cooler air (Fig. 5). On the late afternoon of May 22nd a distant thunderstorm yielded $2.8 \mathrm{~mm}$ of precipitation.

During HartX exceptional clear sky conditions prevailed (Fig. 7). From May 13th to May 19th at $58 \%$ of the hourly times zero cloud cover was observed. During the rest of the time isolated $\mathrm{Ci}$ fib and $\mathrm{Cu}$ hum clouds (above the Black Forest and the Vosges) occurred. But the direct solar radiation at the site itself was influenced by the cumulus clouds only rarely.
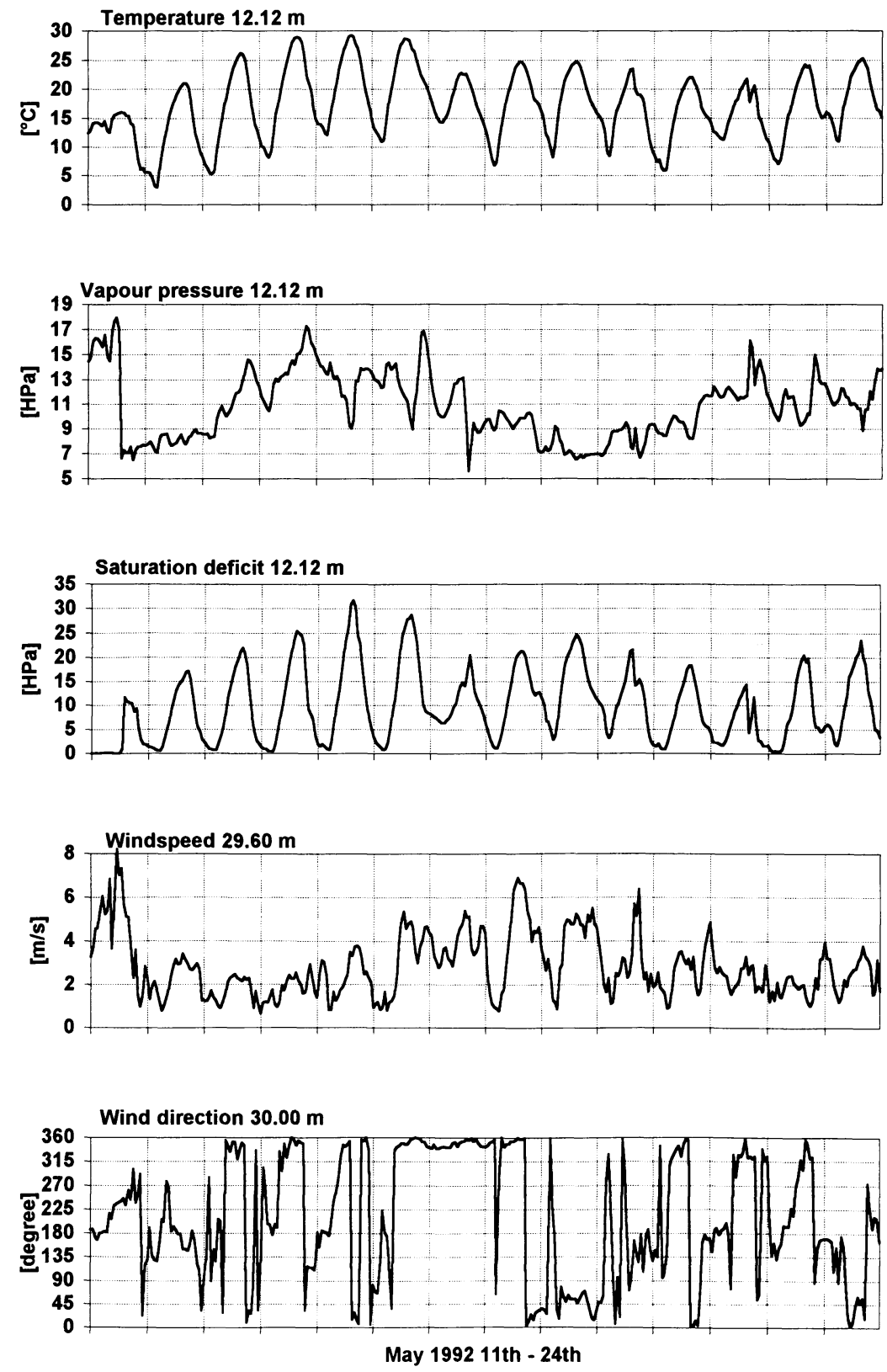

Fig. 5. Climatic diagram of the HartX period May 11th to 24th 1992 
Table 3. Mean Daily Totals $\left(W h / m^{2}\right)$ of the Net Radiation $R_{n}$, the Global Radiation $R_{s} \downarrow$, the Reflected Global Radiation $R_{s} \uparrow$, the Atmospheric Longwave Radiation $R_{l} \downarrow$ and the Upward Thermal Radiation $R_{l} \uparrow$ at Hartheim Pine Stand

\begin{tabular}{llcccc}
\hline & $R_{n}$ & $R_{s} \downarrow$ & $R_{s} \uparrow$ & $R_{l} \downarrow$ & $R_{l} \uparrow$ \\
\hline $\begin{array}{l}\text { May } \\
1974-1988\end{array}$ & 3394 & 4747 & 436 & 8275 & 9192 \\
May 1992 & 3292 & 5406 & 481 & 7842 & 9475 \\
$11-24$ May & 4456 & 7169 & 644 & 7653 & 9722 \\
1992 & & 7658 & 692 & 7767 & 9964 \\
$13-19$ May & 4769 & & & & \\
1992 & & & &
\end{tabular}

Table 4. Mean Hourly Totals $\left(W h / m^{2}\right)$ of the Net Radiation $R_{n}$, the Global Radiation $R_{s} \downarrow$, the Reflected Global Radiation $R_{s} \uparrow$, the Atmospheric Longwave Radiation $R_{l} \downarrow$ and the Upward Thermal Radiation $R_{l} \uparrow$ at Hartheim Pine Stand, Average mean Values May (1974-1988) and mean Values May 11th-24th 1992 during HartX

\begin{tabular}{|c|c|c|c|c|c|c|c|c|c|c|c|c|c|}
\hline 1974-1988 & $0-1$ & $1-2$ & $2-3$ & $3-4$ & $4-5$ & $5-6$ & $6-7$ & $7-8$ & $8-9$ & $9-10$ & $10-11$ & $11-12$ & CET \\
\hline$R_{s} \downarrow$ & 0 & 0 & 0 & 0 & 2 & 31 & 109 & 211 & 324 & 430 & 511 & 556 & \\
\hline$R_{s} \uparrow$ & 0 & 0 & 0 & 0 & 0 & 4 & 13 & 21 & 30 & 39 & 44 & 48 & \\
\hline$R_{l} \downarrow$ & 328 & 327 & 326 & 327 & 327 & 328 & 331 & 337 & 343 & 349 & 355 & 359 & \\
\hline$R_{l} \uparrow$ & 361 & 359 & 356 & 355 & 353 & 354 & 362 & 373 & 383 & 391 & 399 & 405 & \\
\hline$R_{n}$ & -33 & -32 & -30 & -28 & -25 & 2 & 66 & 153 & 254 & 349 & 422 & 462 & \\
\hline 1974-1988 & $12-13$ & $13-14$ & $14-15$ & $15-16$ & $16-17$ & $17-18$ & $18-19$ & $19-20$ & $20-21$ & $21-22$ & $22-23$ & $23-24$ & CET \\
\hline$R_{s} \downarrow$ & 560 & 537 & 480 & 404 & 300 & 188 & 88 & 19 & 0 & 0 & 0 & 0 & \\
\hline$R_{\mathrm{s}} \uparrow$ & 48 & 47 & 43 & 37 & 29 & 20 & 10 & 2 & 0 & 0 & 0 & 0 & \\
\hline$R_{l} \downarrow$ & 365 & 368 & 372 & 371 & 369 & 362 & 354 & 346 & 339 & 336 & 332 & 330 & \\
\hline$R_{l} \uparrow$ & 410 & 413 & 415 & 415 & 413 & 408 & 401 & 390 & 379 & 373 & 368 & 365 & \\
\hline$R_{n}$ & 467 & 445 & 395 & 323 & 227 & 122 & 31 & -27 & -39 & -37 & -36 & -34 & \\
\hline HartX & $0-1$ & $1-2$ & $2-3$ & $3-4$ & $4-5$ & $5-6$ & $6-7$ & $7-8$ & $8-9$ & $9-10$ & $10-11$ & $11-12$ & CET \\
\hline$R_{s} \downarrow$ & 0 & 0 & 0 & 0 & 2 & 50 & 178 & 335 & 493 & 654 & 783 & 835 & \\
\hline$R_{s} \uparrow$ & 0 & 0 & 0 & 0 & 0 & 7 & 21 & 36 & 47 & 57 & 65 & 67 & \\
\hline $\mathbf{R}_{l} \downarrow$ & 312 & 313 & 311 & 307 & 304 & 296 & 286 & 288 & 293 & 294 & 301 & 310 & \\
\hline$R_{l} \uparrow$ & 377 & 371 & 367 & 362 & 357 & 355 & 368 & 385 & 399 & 411 & 425 & 435 & \\
\hline$R_{n}$ & -64 & -58 & -56 & -56 & -51 & -16 & 75 & 201 & 340 & 480 & 595 & 643 & \\
\hline HartX & $12-13$ & $13-14$ & $14-15$ & $15-16$ & $16-17$ & $17-18$ & $18-19$ & $19-20$ & $20-21$ & $21-22$ & $22-23$ & $23-24$ & CET \\
\hline$R_{s} \downarrow$ & 861 & 819 & 744 & 607 & 398 & 265 & 123 & 31 & 0 & 0 & 0 & 0 & \\
\hline$R_{s} \uparrow$ & 69 & 68 & 63 & 55 & 40 & 29 & 15 & 5 & 0 & 0 & 0 & 0 & \\
\hline$R_{l} \downarrow$ & 313 & 337 & 342 & 350 & 355 & 353 & 349 & 345 & 336 & 327 & 321 & 317 & \\
\hline$R_{l} \uparrow$ & 445 & 450 & 454 & 456 & 447 & 441 & 433 & 420 & 404 & 395 & 388 & 382 & \\
\hline$R_{n}$ & 660 & 638 & 569 & 445 & 266 & 146 & 24 & -49 & -68 & -68 & -67 & -65 & \\
\hline
\end{tabular}

In May 1992 a daily mean temperature of $16.5^{\circ} \mathrm{C}$ was observed, which was nearly $3{ }^{\circ} \mathrm{C}$ warmer than the climatological mean. The HartX period (May 11th to 24th) was extraordinarily warm, showing a daily average temperature of $18.2^{\circ} \mathrm{C}$. During this month only half of the long term amount of precipitation was recorded, coming up to $40.4 \mathrm{~mm}$. During HartX we noticed five days of precipitation (May, 11th, 20th, 21st, 22nd and 24th), yielding a sum of only $3.5 \mathrm{~mm}$. Sturm et al. (this issue) report on the measure- ments of soil moisture below the pine stand during the year of 1992 and during HartX.

\section{The Net Radiation and its Components}

There are several investigations concerning the radiation conditions at the Hartheim site (Jaeger and Kessler, 1980; Kessler, 1985b; Keding, 1989; Lehn, 1991; Kessler and Jaeger, 1994). The net radiation and its components have been measured by means of pyranometers (solarimeters) and by 


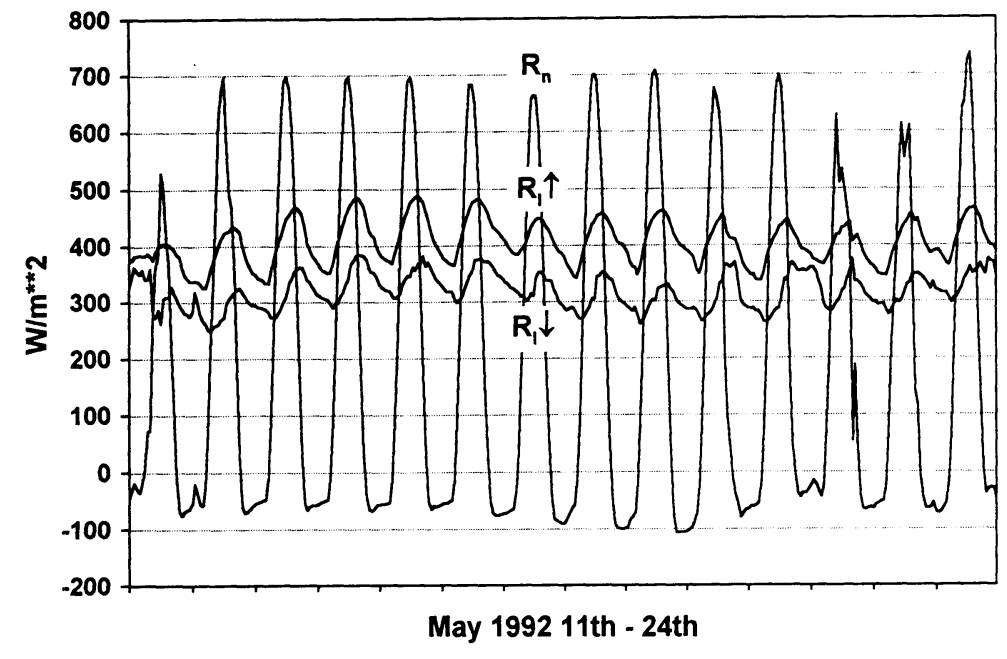

Fig. 6. Course of the net radiation $R_{n}$, the downward atmospheric long-wave radiation $R_{l} \downarrow$ and the upward thermal radiation $R_{l} \uparrow$ above the Hartheim pine stand during the HartX period May 11th to 24th 1992

Table 5. Daily Totals of the Heat Balance Components $\left(W h / m^{2}\right)$ of the Hartheim Pine Stand, $R_{n}$ Net Radiation, $(G+J)$ Soil Stand Heat Flux, H Sensible Heat Flux, גE Latent Heat Flux

\begin{tabular}{|c|c|c|c|c|c|c|c|c|c|c|c|c|}
\hline & $\mathbf{J}$ & $\mathrm{F}$ & $\mathrm{M}$ & A & $\mathrm{M}$ & $\mathbf{J}$ & $\mathbf{J}$ & A & $S$ & $\mathrm{O}$ & $\mathrm{N}$ & $\mathrm{D}$ \\
\hline$R_{n}$ & 69 & 608 & 1422 & 2653 & 3394 & 4092 & 4053 & 3386 & 2242 & 972 & 253 & -5 \\
\hline$G+J$ & 119 & 106 & -14 & -53 & -122 & -142 & -122 & -64 & -6 & 92 & 133 & 133 \\
\hline$H$ & 414 & -53 & -125 & -1117 & -1267 & -1683 & -2036 & -2030 & -842 & -364 & 292 & 453 \\
\hline$\lambda E$ & -602 & -661 & -1283 & -1483 & -2005 & -2267 & -1895 & -1292 & -1394 & -700 & -678 & -581 \\
\hline
\end{tabular}

b) Monthly means for 1992

\begin{tabular}{lrrrrrr} 
& May 11 & & & & & Oct 1 \\
& to 31 & & \multicolumn{1}{l}{ J } & A & S & to 14 \\
$R_{n}$ & 4008 & 3792 & 3816 & 3048 & 2064 & 840 \\
$G+J$ & -168 & -144 & -144 & -120 & 24 & 96 \\
$H$ & -1920 & -1464 & -1992 & -1896 & -696 & -144 \\
$\lambda E$ & -1920 & -2184 & -1680 & -1032 & -1392 & -792
\end{tabular}

c) Mean values for HartX (May 12th to 22nd)

$$
\begin{array}{lc} 
& \text { May 12 } \\
& \text { to } 22 \\
R_{n} & 4656 \\
G+J & -219 \\
H & -2217 \\
\lambda E & -2220
\end{array}
$$

means of Schulze-Däke type net radiometers. An international comparison of net radiometers (Halldin and Lindroth, 1992) pointed out the advantages of the Schulze-Däke-radiometer. All the radiation data reported here are related to the World Radiometric Reference (WRR, 1981).

The net radiation equation is formulated as follows:

$R_{n}=\left(R_{s} \downarrow-R_{s} \uparrow\right)+\left(R_{l} \downarrow-R_{l} \uparrow\right)$,

with the following flux densities:

$R_{n}$ net all-wave radiation, $R_{s} \downarrow$ total downward solar radiation (global radiation), $R_{s} \uparrow$ reflected solar radiation (reflected global radiation), $R_{l} \downarrow$ downward atmospheric long-wave radiation (counter radiation), $R_{l} \uparrow$ total of the upward terrestrial long-wave thermal radiation and the atmospheric long-wave radiation reflected at the surface.

Table 3 shows mean daily totals of all components of the net radiation during HartX compared to the long term values. Table 4 gives mean hourly totals and Fig. 6 shows the pattern during HartX. Gay et al. (this issue) discuss further measurements of $R_{n}$ during the year of 1992 (Table 5). 


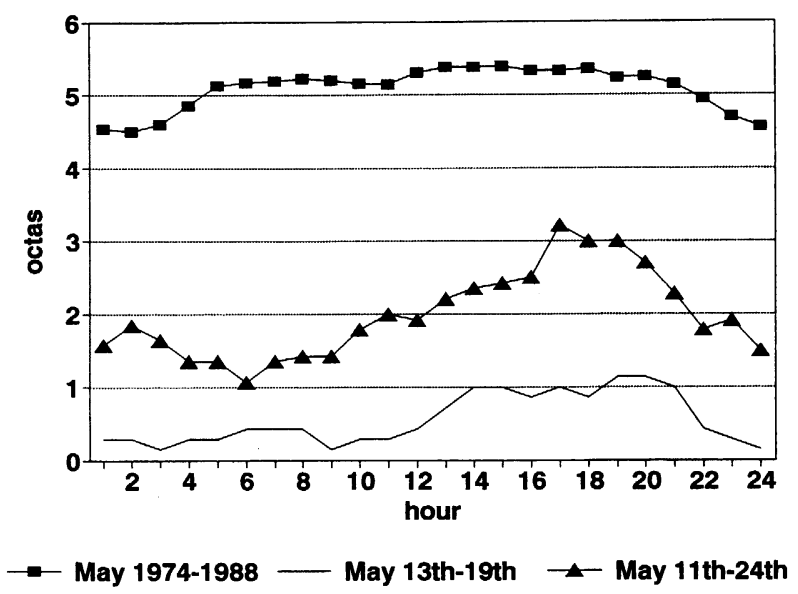

Fig. 7. Daily pattern of the cloud cover in octas at the Bremgarten meteorological observatory $(3.2 \mathrm{~km}$ to the south-east of Hartheim site), average mean values of May (1974-1988), mean values during the HartX period May 11th-24th 1992 and mean values during the extremely cloudless period May 13th-19th 1992

The daily totals of the global radiation $R_{s} \downarrow$ during HartX are $51 \%$ higher than the long term mean value. During the cloudfree period of May 13th to May 19th 1992 (Fig. 7) this even rises to $62 \%$ (!). In contrast, the daily totals of downward atmospheric long-wave radiation $R_{l} \downarrow$ lies under its long-term means, due to low vapour pressure and reduced cloudiness.

It should be pointed out (Table 4), that during HartX the hourly totals of the upward thermal radiation $R_{l} \uparrow$ show higher values and the atmospheric radiation $R_{l} \downarrow$ show smaller values than the long term mean values. This leads to the fact, that the long-wave radiation loss of the forest at night $R_{n}=\left(R_{l} \downarrow-R_{l} \uparrow\right)$ is twice as much during HartX compared to the long term mean value.

The daily maxima of $R_{s} \downarrow$ and $R_{n}$ decreased from May 12th to May 17th due to the increasing atmospheric turbidity (Fig. 6). After the replacement of the airmass at May 17th $R_{s} \downarrow$ and $R_{n}$ reached their former extreme values again. Note, that the minima of $R_{n}=\left(R_{l} \downarrow-R_{l} \uparrow\right)$ during the nights decrease continuously till May 19 th when the net radiation dropped below $-100 \mathrm{Wh} / \mathrm{m}^{2}$. This is due to the progressive heating of the stand during the daytime insolation relative to the reduced heating of the atmosphere. The progressive water vapour reduction simultaneously reduces the longwave incoming radiation.

\section{The Energy Balance}

To describe the energy fluxes at canopy height we use the following simplified energy balance equation. All flux densities are defined as being positive, if they transport energy to the reference level (outer active layer of the pine stand):

$R_{n}+(G+J)+H+\lambda E=0$

with: $R_{n}$ net radiation, $G$ soil heat flux, $J$ stand heat storage per unit of ground area, $H$ sensible heat flux to the atmosphere, $\lambda E$ evaporative heat or latent heat flux ( $\lambda$ latent heat of vaporization of water). Since 1974 we have estimated monthly totals of these terms at the Hartheim site (Schott, 1980; Garthe, 1985; Kessler et al., 1988; Vogt and Jaeger, 1990).

The soil heat flux $G$ is computed by means of a combination method. From the soil surface to a depth of $20 \mathrm{~cm}\left(z_{u}\right)$ we use the rate of change in the heat content in this layer, at deeper levels we use the heat conduction equation (Schott, 1980; Garthe, 1985):

$G=\rho c \int_{0}^{z_{u}} \frac{d T}{d t} d z+k \frac{d T}{d z}$

with: $\rho$ soil density; $c$ specific heat capacity of the soil; $T$ soil temperatures, measured at $1,3,5,10$, 20 and $40 \mathrm{~cm}$ depth; $k$ thermal conductivity; $z$ depth and $t$ time.

$J$ is calculated by means of the rate of change in the heat content of the biomass and the air between soil surface and reference level:

$$
\begin{aligned}
J= & \rho_{b} c_{b} \int_{0}^{z_{b}} \frac{d T_{b}}{d t} d z+\rho_{a} c_{p} \int_{0}^{z_{b}} \frac{d T_{a}}{d t} d z+\rho_{v} \lambda \\
& \times \int_{0}^{z_{b}} \frac{d q}{d t} d z
\end{aligned}
$$

The nomenclature is the same as above; index $b$ means biomass, $a$ air, $v$ water vapour, $z_{b}$ the stand height, $c_{p}$ the specific heat of the air at constant pressure, and $q$ the specific humidity.

According to the specific questions which were looked at, the turbulent energy fluxes $H$ and $\lambda E$ are determined by means of different methods at the Hartheim site in the last 20 years of continuous measurements:

(a) Bowen ratio $(\beta=H / \lambda E)$ - energy balance method (Sverdrup or Albrecht method)

(b) Water balance method (Eq. 6) 
(c) Aerodynamic method

(d) Energy balance equation (Eq. 3); lacking terms $(H$ or $\lambda E)$ are calculated as a residual

It came out that in calculating average mean values or in examining specific features of the mean daily or yearly pattern at the Hartheim site the methods (a), (b) and (d) or a combination of these methods are particularily suitable.

Besides the meteorological and hydrological methods presented above further special estimates including biological methods were carried out during HartX (sonic and one-propeller eddy correlation systems, interchanging Bowen ratio energy system, sap flow measurements, lysimeters).

The water balance equation is formulated as follows:

$$
E=P-S+\Delta S M,
$$

with $E$ evapotranspiration, $P$ precipitation, $S$ percolation, $\Delta S M$ change of soil moisture.

As percolation is assumed to be negligible at the Hartheim pine stand (Hädrich, 1979), the determination of $E$ is reduced to the recording of the precipitation $P$ above the canopy (Jaeger, 1984a) and the measurement of the water content in the soil (Sturm et al., this issue).

Table 5 and Fig. 8 present the mean yearly pattern of all fluxes over the period 1974-1988. Here, the flux of latent energy $\lambda E$ was estimated by means of the water balance method (b) and $H$ was calculated in a subsequent step by means of the heat balance equation (d). During our estimates (Kessler et al., 1988) we discovered, that the Bowen ratio-energy balance method (a) frequently yields too high totals for $\lambda E$, giving $\lambda E>\lambda P$.

It should be pointed out that in the dry region of the southern Rhine valley plain the latent heat flux $\lambda E$ of the pine forest rises to its maximum in the early months of the summer season. During this time soil water availability is usually not limiting, the vapour pressure of the air is relatively low (Kessler and Jaeger, 1994) and energy consumption for evaporation can be well supplied by $R_{n}$. These conditions all favour a high evapotranspiration.

The maximum of the flux of sensible heat $H$ is shifted to the late summer months, when the soil moisture is close to the wilting point (Kessler et al., 1988; Sturm et al., this issue) and the net radiation shows high values. During two months July and August - the turbulent sensible heat flux mean $\mathrm{H}$ exceeds the mean of $\lambda E$. In September the latent heat flux shows a second, smaller peak (Fig. 8) when more soil water becomes available in fall, associated to sufficient net radiation values. Whereas $R_{n}, H$ and $(G+J)$ show only one maximum, the yearly pattern of the latent heat flux shows two peaks due to the drying out of the soil, like the Mediterranean type of the yearly $\lambda E$ pattern (Kessler, 1985a).

Considerably high values of $\lambda E$ are observed above the pine stand during the winter season, because the transpiration $E_{T r}$ in coniferous forests is not stopped in winter. Moreover the

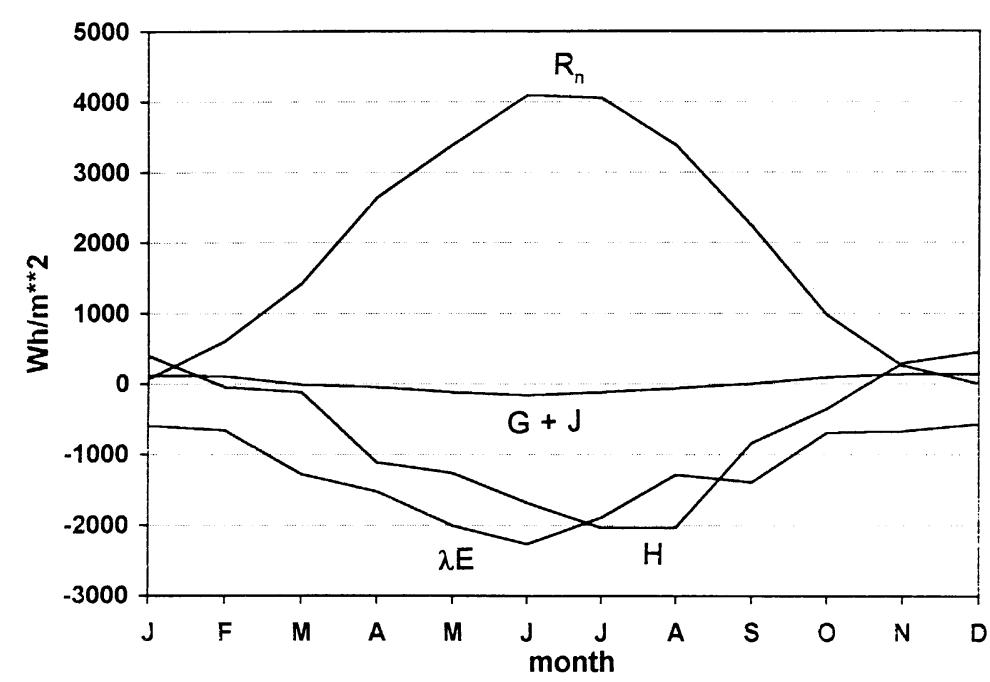

Fig. 8. Average monthly mean values of daily totals of the heat balance components of the Hartheim pine stand from the years 1974 to 1988 in $\mathrm{Wh} / \mathrm{m}^{2}, R_{n}$ net radiation, $(G+J)$ soil stand heat flux, $H$ sensible heat flux, $\lambda E$ latent heat flux 
magnitude of winterly interception values $E_{l n}$ is in the same range as in the summer season (Table 2). The net radiation $R_{n}$ in winter is estimated to be near zero (Fig. 8). Thus, the amount of $\lambda E$ must be alimentated essentially by the flux of sensible heat $H$ directed to the canopy, as the soil-stand heat flux $(G+J)$ is small, too.

Table 5 also presents the energy balance measurements during summer 1992 (May 11th to October 14th; see Gay et al., this issue). With the exception of May 1992 the values and therefore the pattern are quite the same as the long term values despite different weather conditions.

The comparison of the heat fluxes in May shows, that HartX represents a period which is exceptional in every respect (Table 5). The clear sky conditions during HartX offered ideal conditions to carry out comparative estimates of the evapotranspiration $E$ in relation to comparative estimates of the flux of latent energy. Unfortunately we are not able to apply these results to normal weather conditions. The mean windspeed was very low during HartX (Fig. 5). Thus the dependence of the different methods in determining the turbulent flux of latent heat on the windspeed could not be studied adequately.

Finally we present in Table 5 estimates of the energy balance data of the HartX days May 12th to 22 nd ( $H$ and $\lambda E$ from Gay et al., this issue). It should be pointed out that over these days the term $\lambda E$ of the forest does not exceed substantially the normal level for the month of May, though we observed an over-normal high gain of $R_{n}{ }^{-}$ values and a relatively high content of soil moisture (Sturm et al., this issue), thus $H \sim \lambda E$. In other years $H \geqslant \lambda E$ is observed only in the late summer when the soil moisture is low.

This effect of reduction to the evapotranspiration steered by the forest cannot be observed above a grass surface in the surroundings, $3.2 \mathrm{~km}$ south-east of the Hartheim station (Wicke and Bernhofer, this issue). From May 17th to 22nd the grass evaporated nearly twice the amount of water than the forest in spite of a lower net radiation above grass compared to that of the forest. Unfortunately we have no soil moisture measurements of this site, so a detailed comparison of the two surface types is not possible.

The question concerning the pine forest is indeed whether the water conduction systems of the trees reached the upper limits of its efficiency during the HartX period with its extraordinarily high net radiation values, high water vapour saturation deficit of the air and high values of soil moisture. We would suggest that the pines in Hartheim were adapted to their climate during the last 30 years. And that they could not react according to the supply of water and energy and to the atmospheric conditions during a relatively short and exceptional weather situation.

\section{Conclusion}

The aims of the long-term investigations at the Hartheim site of the Department of Meteorology of Freiburg University are measurements of the radiation, energy and water budgets of a pine forest. We calculate long term daily and yearly patterns, the interannual variability, the influence of weather conditions on the budget terms, and similar climatological influences. Furthermore we aim to investigate the influence of alterations to the forest ecosystem caused e.g. by stand growth, clearances or other forest management effects etc.

A project like that requires a restriction of the measurements to the main components if one intends to perform it for years or even decades. Besides that special operation periods are necessary to solve particular problems in short time scales. In May 1992 such a period was carried out (HartX 92) jointly by meteorologists, hydrologists, biologists and geographers. In addition to the routine monitoring of the Meteorological Institute special measurements were undertaken in the summer of 1992.

Essentials of the HartX campaign seen from our point of view are:

a) Measurements of the latent heat flux using several independent methods (energy and water balance, sonic and one-propeller eddy correlation systems, interchanging Bowen ratio energy system, sap flow measurements, lysimeter) supported each other.

b) Measurements of the evapotranspiration of the understory vegetation and of soil evaporation revealed that the understory is of considerable importance.

c) Measurements of soil moisture with several methods are advantageous (not by the gravimetric method only). 
d) Comparison of the pine stand data with measurements above a grass surface in the neighbourhood showed much higher evapotranspiration at the grass site.

e) A long term run of a one-propeller/eddy correlation system (OPEC) to estimate the sensible heat flux in the summer of 1992.

The fair weather conditions during HartX favoured the measurements considerably. We discuss the long term measurements of the energy and water budget terms (1974-1988) in connection with the HartX measurements.

Thus we yield one important question. During HartX the pine forest evaporated about as much as the long term mean because it had a high soil water availability and extraordinarily favourable atmospheric conditions for evapotranspiration. A grass surface in the neighbourhood evaporated nearly double the amount of water under equivalent atmospheric conditions and smaller amounts of net radiation. The soils of both sites are nearly equal. A possible different gain of water due to dew formation at both sites cannot explain the great differences in evapotranspiration because the dew quantity is small in energy terms and occurs only during a few nights (Hofmann, 1955; Kessler, 1985a).

We interpret this unexpected behaviour of the forest as follows. For more than 30 years the pine forest has been adapted to the natural environment, its sapflow systems in particular. Obviously the water conduction systems of the trees reached the upper limits of their efficiency during the extraordinary weather conditions of HartX. The evapotranspiration could not be enhanced further.

To be able to model realistically the soilvegetation-atmosphere system this limit should be known. Obviously it is difficult to determine the upper limit of evapotranspiration because the appropriate atmospheric conditions are rare in general and apart from this the data base which is necessary can be provided only by long-term measurements. Moreover this limiting value is unique and cannot be derived from other ecosystems easily. In this respect the weather of HartX was both fortunate and fortuitous.

The example shows further that the concept of "potential evapotranspiration" which is often practically used to determine actual evapotrans- piration values is questionable when supported only by the atmospheric conditions and the soil moisture.

With respect to the discussion of "Global Change" the comparison of the longterm measurements with the HartX data at the Hartheim site showed that it is desirable to begin to monitor not only the primitive elements of climate (temperature, precipitation etc.) but also parameters of physical climatology (all components of the radiation, energy and water budgets) at least at a few ecosystems. The reasons for changes in ecosystems in the future can be detected only by means of such data sets. Besides the long-term measurements of physical climatology parameters we need long-term monitoring of biometric parameters because their natural and man-made changes influence the energy and water budgets.

\section{References}

Baumgartner, A., 1990: Energiehaushalt der Erde. In: Baumgartner, A., Liebscher, H. J. (Hrsg.) Allgemeine Hydrologie. Berlin, Stuttgart: Borntraeger, 129-191.

Garthe, H.-J., 1985: Über das langjährige Verhalten der Energiehaushaltskomponenten eines mitteleuropäischen Kiefernwaldes. Diss. Geowiss. Fak. Univ. Freiburg, 107 pp.

Gay, L. W., Vogt, R., Bernhofer, C., Blanford, J. H., 1996: Flux agreement above a scots pine plantation. Theor. Appl. Climatol., 53, 33-48.

Gay, L. W., Vogt, R., Kessler, A., 1996: The May-October energy budget of a scots pine plantation at Hartheim, Germany. Theor. Appl. Climatol., 53, 79-94

Hädrich, F., 1979: Der Wasserhaushalt einer ZweischichtPararendzina unter Kiefernjungbeständen im Trockengebiet am südlichen Oberrhein. Mitt. Dtsch. Bodenk. Ges., 29, 149-158.

Halldin, S., Lindroth, A., 1992: Errors in net radiometry: comparison and evaluation of six radiometer designs. $J$. Atmos. Oceanic Technol., 9, 762-783.

Hantel, M., 1989: The present global surface climate. Landolt-Börnstein, Zahlen und Funktionen, Neue Serie, Gruppe V, Bd. 4, Teilbd. c Klimatologie, Teil 2, 117-474.

Heiderich, S., 1989: Die Bedeutung und Verwendung von Blattflächenindex und Blattflächendichte unter besonderer Berücksichtigung der Forstmeteorologie, nebst einer praktischen Bestimmung dieser Größen in einem Kiefernwald-(pinus sylvestris L.) bestand. Dipl. Arb. am Meteorol. Inst. der Univ. Freiburg, 68 pp.

Hofmann, G., 1955: Die Thermodynamik der Taubildung. Ber. Deutscher Wetterd., 18, 45 pp.

Jaeger, L., 1978: Die klimatologische Meßstation Hartheim des Meteorologischen Instituts der Universität Freiburg i.Br. Ber.Naturf. Ges. Freiburg, 68, 47-73. 
Jaeger, L., 1984a: Zehn Jahre Niederschlagsmessungen über einem Kiefernbestand im angehenden Stangenholzalter. Wetter und Leben, 36, 149-158.

Jaeger, L., 1984b: Climatology of wind profile parameter estimates above a growing pine forest. Arch. Met. Geoph. Biocl. Ser. B, 34, 161-179.

Jaeger, L., Kessler, A., 1980: Langzeitmessungen der Strahlungsbilanz und ihrer Komponenten über einem Kiefernbestand der südlichen Oberrheinebene. Allg. Forst-u. Jagdztg., 151, 210-218.

Keding, I., 1989: Klimatologische Untersuchung über die atmosphärische Gegenstrahlung und Vergleich von Berechnungsverfahren anhand langjähriger Messungen im Oberrheintal. Ber. Deutscher Wetterd., 178, 72 pp.

Kessler, A., 1985a: Heat Balance Climatology. World Survey of Climatology, Vol.1A. Amsterdam, London, New York, Tokyo: Elsevier, 224 pp.

Kessler, A., 1985b: Über die kurzwellige Albedo eines Kiefernwaldes. Eine klimatologische Langzeitstudie. Meteorol. Rdsch., 38, 82-91.

Kessler, A., Jaeger, L., 1994: Mittlere Tages- und Jahresgänge der Strahlungsbilanz und ihrer Komponenten über einem südwestdeutschen Kiefernwald. Eine klimatologische Interpretation. Erdkunde, Arch.f. wiss. Geogr., 48, 14-33.

Kessler, A., Müller, R., Jaeger, L., 1988: Der Wasserhaushalt eines Kiefernwaldes und Wechselwirkungen mit dem Energiehaushalt. Erdkunde, Arch. f. wiss. Geogr., 42, 177-188.

Künstle, E., Mitscherlich, G., Hädrich, F., 1979: Gaswechseluntersuchungen in Kiefernbeständen im Trockengebiet der Oberrheinebene. Allg. Forst- u. Jagdztg., 150, 205228.
Lehn, W. H., 1991: A two-band clear sky albedo model for a pine forest. Meteorol. Rdsch., 43, 129-139.

Merkel, H., 1987: Der Jahrring der Kiefer als klimatologische Datenquelle. Ber. Deutscher Wetterd., 172, 48 pp.

Miller, D. H., 1981: Energy at the Surface of the Earth. New York, London, Toronto, Sydney, San Francisco: Academic Press, 516 pp. (Intern. Geoph. Series, Vol. 27).

Parlow, E., 1996: The Regional Climate Project REKLIP An Overview. Theor. Appl. Climatol., 53, 3-7.

Schott, R., 1980: Untersuchungen über die Energiehaushaltskomponenten in der atmosphärischen Grenzschicht am Beispiel eines Kiefernbestandes in der Oberrheinebene (Hartheim/Rh.). Ber. Deutscher Wetterd., 153, 58 pp.

Sturm, N., Reber, S., Kessler, A., Tenhunen, J., 1996: Soil moisture variation and plant water stress at the Hartheim scots pine plantation. Theor. Appl. Climatol., 53, 123-133.

Vogt, R., Jaeger, L., 1990: Evaporation from a pine forest using the aerodynamic method and Bowen ratio method. Agric. Forest Meteor., 50, 39-54.

Wedler, M., Heindl, B., Hahn, S., Köstner, B., Bernhofer, Ch., Tenhunen, J., 1996: Model-based estimates of water loss from "patches" of the understory mosaic of the Hartheim Scots pine plantation. Theor. Appl. Climatol., 53, 135-144.

Wicke, W., Bernhofer, Ch., 1996: Energy balance comparison of the Hartheim pine plantation and an adjacent grassland site during the HartX experiment. Theor. Appl. Climatol., 53, 49-58.

Authors' address: Prof. Dr. A. Kessler and Priv. Doz. Dr. L. Jaeger, Meteorologisches Institut der Universität Freiburg, Werderring 10, D-79085 Freiburg i. Br., Federal Republic of Germany. 